\title{
Acoustic signals in the communities of Bryodemini (Orthoptera: Acrididae: Oedipodinae): segregation of communication channels through the temporal divergence of acoustic activity peaks and the emergence of the dusk chorus
}

\author{
Акустические сигналы в сообществах Bryodemini \\ (Orthoptera: Acrididae: Oedipodinae): \\ разделение каналов связи за счёт временно́го расхождения пиков \\ акустической активности и формирования "сумеречного хора"
}

\section{D.Yu. Tishechkin \\ A.Ю. Тишечкин}

\footnotetext{
Department of Entomology, Faculty of Biology, M.V. Lomonosov Moscow State University, Vorobyevy Gory, Moscow 119991, Russia. Email: macropsis@yandex.ru.

Кафедра энтомологии Биологического факультета Московского государственного университета имени М.В. Ломоносова, Воробьёвы Горы, Москва 119991, Россия.
}

KEY WORDS: grasshoppers, Acrididae, Oedipodinae, Bryodemini, song, signal, community, acoustic communication, flight display, dusk chorus.

КЛЮЧЕВЫЕ СЛОВА: саранчовые, Acrididae, Oedipodinae, Вryodemini, сигнал, сообщество, акустическая коммуникация, демонстрационный полёт, сумеречный хор.

ABSTRACT. The sounds produced by four sympatric species of Bryodemini from South Siberia during flight displays are described. In spite of distinct interspecific differences in signal temporal pattern, Bryodema luctuosum, Bryodemella holdereri and Angaracris barabensis sing during daytime, whereas B. tuberculatum dilutum usually demonstrates only short and sharp peak of acoustic activity after sunset sometimes forming so-called dusk chorus. Since the abundance of Bryodemini usually is remarkably high, it can be assumed that during flight displays acoustic signals of different species suffer mutual interference even though they differ distinctly from each other in temporal pattern. Apparently, this is the reason for temporal shift of $B$. tuberculatum dilutum acoustic activity peak and the emergence of dusk chorus in this species.

РЕЗЮМЕ. Описаны издаваемые во время демонстрационных полётов звуки четырех симпатрических видов Bryodemini из степных районов Сибири. Несмотря на то, что сигналы всех видов отчётливо различаются по амплитудно-временно́му рисунку, Bryodema luctuosum, Bryodemella holdereri и Angaracris barabensis поют исключительно в течение дня, в то время как у B. tuberculatum dilutum обычно наблюдается лишь короткий резкий пик акустической активности после захода солнца (так называемый “сумеречный хор”). Поскольку Bryodemini нередко достигают очень высокой численности, можно предположить, что при массовых демонстрационных полётах сигналы разных видов могут заглушать друг друга даже несмотря на чёткие межвидовые различия. Вероятно, именно это привело к смещению периода акустической активности $B$. tuberculatum dilutum на вечерние часы и к формированию “сумеречного хора” у этого вида.

\section{Introduction}

Grasshoppers of the tribe Bryodemini Bey-Bienko, 1930 (Orthoptera: Acrididae: Oedipodinae) is a distinctive element of steppe and semidesert landscapes of South-Eastern Kazakhstan, South Siberia, Mongolia and China due to their remarkable flight displays accompanied by sound production. The ranges of the most representatives of the tribe are restricted to this region or its parts; only Bryodemella tuberculatum (Fabricius, 1775) has transpalaearctic distribution.

But for irregular short signals emitted when sitting on the ground, males of Bryodemini produce sounds during flight displays. Consequently, recording of their sounds is possible only under natural conditions. For this reason data on the songs of these insects are rather scarce. Descriptions of the sounds of B. tuberculatum 
from european populations were published by several authors [e.g. Ragge \& Reynolds, 1998], first oscillograms of the sounds of two asiatic representatives of the tribe are given in Xi et al. [1992]. Somewhat later Benediktov [1998] provided oscillograms and descriptions of the sounds of four species from Tyva (South Siberia) and adjacent territories of Mongolia. Illustrated description of the sounds of Bryodema gebleri (Fischer-Waldheim, 1836) is also given in Savitsky \& Lekarev [2007].

In the animals using acoustic signals (songs) for intraspecific communication, the members of every multispecies community differ from each other in signal parameters thus each species occupying his own place in the acoustic environment of the biotope. In the grasshoppers of the subfamily Gomphocerinae segregation of "acoustic niches" within the community is provided by both qualitative and quantitative differences in the temporal patterns of the songs [Bukhvalova, 2006; Tishechkin, 2008; Tishechkin \& Bukhvalova, 2010]. As a result, in certain communities up to 10-11 species can coexist and simultaneously use acoustic communication [Tishechkin \& Bukhvalova, 2010].
Bryodemini communities in the steppes of South Siberia are much less species-rich and include only three or four species. On the other hand, abundance of these large insects usually is remarkably high. In the sunny days in the steppes of Southern Tyva or Transbaikalia one can see hundreds of individuals performing flight displays at a time and producing their signals in unceasing loud chorus masking all other sounds. The present article seeks to describe the mechanism of segregation of communication channels under such conditions.

\section{Material and methods}

The field studies were conducted in Buryatia and Chita Area (Eastern Siberia). Also, the sounds of Bryodemella tuberculatum tuberculatum (Fabricius, 1775) from Volgograd Area are described here for comparison with these of the siberian subspecies, B. tuberculatum dilutum (Stoll, 1813). The list of species investigated with the data for recordings is given in the Table.

Table. Data for recordings of sounds of the studied species of Bryodemini. Таблица. Данные о записях сигналов изученных видов Bryodemini.

\begin{tabular}{|c|c|c|}
\hline Species & Locality, date and number of specimens & $\begin{array}{l}\text { Air temperature } \\
\text { during recording, } \\
{ }^{\circ} \mathrm{C}\end{array}$ \\
\hline \multirow{2}{*}{$\begin{array}{l}\text { Bryodema luctuosum } \\
\text { (Stoll, 1813) }\end{array}$} & $\begin{array}{l}\text { 1. Buryatia, Selenga River valley } 5 \mathrm{~km} \mathrm{~N} \text { of Novoselenginsk } \\
\text { Town, 9.VII.2007. } 3 \square \square \text {. }\end{array}$ & $31-32$ \\
\hline & $\begin{array}{l}\text { 2. Buryatia, Temnik River } 4-5 \mathrm{~km} \mathrm{~N} \text { of Selenduma Town, } \\
\text { 13.VII.2007. } 1 \square \text {. }\end{array}$ & 28 \\
\hline \multirow[b]{2}{*}{$\begin{array}{l}\text { Bryodemella holdereri } \\
\text { (Krauss, 1901) }\end{array}$} & $\begin{array}{l}\text { 1. Buryatia, Temnik River } 4-5 \mathrm{~km} \mathrm{~N} \text { of Selenduma Town, } \\
\text { 12-13.VII.2007. } 4 \square \square .\end{array}$ & 28,32 \\
\hline & $\begin{array}{l}\text { 2. SE of Chita Area, Klichkinskiy Mtn. Ridge at the crossing } \\
\text { with Urulyunguy River (15 km W of Klichka Town), } \\
\text { 23.VII.2003. } 1\end{array}$ & $28-30$ \\
\hline $\begin{array}{l}\begin{array}{l}\text { B. tuberculatum tuberculatum } \\
\text { (Fabricius, 1775) }\end{array} \\
\end{array}$ & $\begin{array}{l}\mathrm{N} \text { of Volgograd Area, Kamyshin Region, env. } \\
\text { Shcherbakovka Village, 13.VII.2005.3 }\end{array}$ & 31 \\
\hline \multirow{4}{*}{$\begin{array}{l}\text { B. tuberculatum dilutum } \\
\text { (Stoll, 1813) }\end{array}$} & $\begin{array}{l}\text { 1. Buryatia, the valley of Irkut River } 3-4 \mathrm{~km} \mathrm{~W} \text { of Mondy } \\
\text { village ( } 80 \mathrm{~km} \text { W of Kyren), 29-30.VI.2007. } 4 \square \square .\end{array}$ & $26,28-29$ \\
\hline & $\begin{array}{l}\text { 2. Buryatia, Selenga River valley } 5 \mathrm{~km} \mathrm{~N} \text { of Novoselenginsk } \\
\text { Town, 10.VII.2007. } 1 \square \text {. }\end{array}$ & 20 \\
\hline & $\begin{array}{l}\text { 3. Buryatia, Barguzin Valley, Ina River in the env. of Ina } \\
\text { Village (50 km NE of Barguzin Town), 19.VII.2007. } 1 \square . \\
\end{array}$ & 17 \\
\hline & $\begin{array}{l}\text { 4. SE of Chita Area, Klichkinskiy Mtn. Ridge at the crossing } \\
\text { with Urulyunguy River (15 km W of Klichka Town), } \\
\text { 23.VII.2003. } 1 \square \text {. }\end{array}$ & $28-30$ \\
\hline \multirow{3}{*}{$\begin{array}{l}\text { Angaracris barabensis } \\
\text { (Pallas, 1773) }\end{array}$} & $\begin{array}{l}\text { 1. Buryatia, Selenga River valley } 5 \mathrm{~km} \text { N of Novoselenginsk } \\
\text { Town, } 9-10 . \text { VII.2007. } 6 \square \square\end{array}$ & $31-32$ \\
\hline & $\begin{array}{l}\text { 2. Buryatia, Temnik River } 4-5 \mathrm{~km} \mathrm{~N} \text { of Selenduma Town, } \\
\text { 13.VII.2007.3 } \square \square\end{array}$ & 28 \\
\hline & $\begin{array}{l}\text { 3. SE of Chita Area, Klichkinskiy Mtn. Ridge at the crossing } \\
\text { with Urulyunguy River (15 km W of Klichka Town), } \\
\text { 23.VII.2003.2 }\end{array}$ & $28-30$ \\
\hline
\end{tabular}


Recordings of the songs were made from freelyflying insects under natural conditions with the microphone MD-382 (upper frequency limit $12.5 \mathrm{kHz}$ ) and either cassette recorder Elektronika-302-1 (upper frequency limit $10 \mathrm{kHz}$, recordings made in 2003) or minidisk recorder Sony Walkman MZ-NH900 (sampling frequency $44.1 \mathrm{kHz}$; recordings made in 2005 and 2007). In all cases manual mode of recording level control was used. Air temperature was measured in the shade during or immediately after recording in the place where the singing insect was flying.

In 2007 in different localities in Buryatia local summer time of the onset of the morning and evening peaks of acoustic activity of $B$. tuberculatum dilutum was registered.

The specimens whose signals were recorded are deposited in the collection of the Zoological Museum of M.V. Lomonosov Moscow State University.

\section{Results}

The males of all Bryodemini studied produce their sounds by specific movements of the wings during flight displays. In so doing they fly in a wave-like path moving up and down; the rhythm of the movements corresponds with syllable repetition period. Sometimes singing male flying into the wind moves up and down for more than a minute almost on the same place about $1-2 \mathrm{~m}$ above the ground.

In Bryodema luctuosum (Stoll, 1813) the song sounds as a succession of short clicks following each other with a period approximately from 100 up to $850 \mathrm{~ms}$ (Figs 16). Oscillographic analysis shows that each syllable includes two high-amplitude pulses usually followed by low-amplitude one (Figs 5-6). Insects perform their flight displays only during daytime flying at the height of $1-2 \mathrm{~m}$ above the ground.

In Bryodemella holdereri (Krauss, 1901) the song is similar to this of the previous species, but the syllable repetition period is shorter and averages 140-340 ms (Figs 7-13). Each syllable consists of three pulses, but the initial and the end ones have very low amplitude and as a rule are indistinguishable on oscillograms (Figs 1113). Similarly, the males of this species perform their flight displays during daytime.

B. tuberculatum dilutum is also a common and abundant species in the steppes of South Siberia, but in sunny days one can hear only crepitation of males flying from one spot to another for a distance of few meters when disturbed by approaching men. This is a short sound lasting for about 1.5-2 s. It consists of short syllables or pulses (Figs 28, 30, 32). In certain individuals low- and high-amplitude pulses alternate, in other ones the pulses of various shape and amplitude follow each other quite randomly. The amplitude of the sound gradually decreases on oscillograms because the flying insect moves away from the microphone. We have not found any significant differences between the sounds of this kind in B. tuberculatum tuberculatum and B. tuber- culatum dilutum (Figs 29, 31, 33 and 28, 30, 32 respectively).

In the evening, when all other steppe grasshoppers are no longer singing, the males of $B$. tuberculatum dilutum start their flight displays. The male flies in uneven circles about $40-50 \mathrm{~m}$ in diameter at the height up to 4-5 $\mathrm{m}$ above the ground. For this reason the amplitude of signals on oscillograms varies greatly with the distance to the microphone. Usually the time of the beginning of the flights fell within a period from 10 to 11 p.m. (local summer time), i.e. approximately from one to two hours after sunset. In contrast to other Bryodemini studied, in B. tuberculatum dilutum the time of acoustic activity is rather short and usually lasts from 10-15 minutes to some half an hour.

If the insects are numerous enough, they form a dusk chorus similar to this in tropical animals. We have observed this phenomenon several times in Chita Area (Klichkinskiy Mtn. Ridge). About 1-2 hours after sunset, when it was almost dark, hundreds of grasshoppers suddenly started their flight displays all together. 10-15 minutes later they ceased flying no less synchronously and only two or three individuals remained in the air for about 10-20 minutes more. The dusk chorus was observed rather often, but not every evening. In all other localities population density was not so high and only several individuals at a time were heard. Occasionally, flight displays in this species were observed also early in the morning at the sunrise (about 4-6 a.m., local summer time).

The valley of Irkut River was the only place, where flight displays of $B$. tuberculatum dilutum were observed one or two hours before sunset and, if the weather was cloudy, occasionally also during daytime.

The song of $B$. tuberculatum dilutum consists of prolonged syllables following each other with a period of 400-900 $\mathrm{ms}$ at $28-29^{\circ} \mathrm{C}$ (Figs 14-16, 18-21 and 2326). In B. tuberculatum tuberculatum we have observed the behaviour similar to flight display only once. The male disturbed by man produced several short syllables when flying from one spot to another (Figs 17, 22 and 27). The structure of the signal produced somewhat differed from that in B. tuberculatum dilutum; on the other hand, according to Ragge \& Reynolds [1998], duration of syllables in nominotypical (european) subspecies averages $0.4-0.5 \mathrm{~s}$, i.e. is approximately the same as in $B$. tuberculatum dilutum in our recordings made at $20{ }^{\circ} \mathrm{C}$.

In the song of Angaracris barabensis (Pallas, 1773) syllables consist of more or less uniform pulses separated by distinct gaps (Figs 34-41). The number of pulses per syllable usually averages $6-8$, only rarely certain syllables include up to $10-15$ pulses each (Figs 38 and 41). Syllable repetition period varies from 300 to about $530 \mathrm{~ms}$ at the temperature $28-31^{\circ} \mathrm{C}$. Singing males usually perform flight displays at the height of no more than 1.5-2 m remaining almost on the same place or moving forward only short distance. As in B. luctuosum and $B$. holdereri, in $A$. barabensis we have observed flight displays only during daytime. 


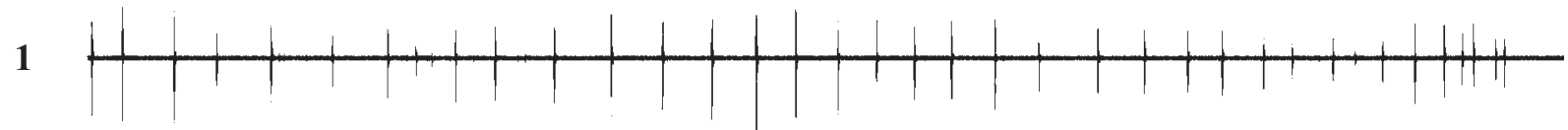

Buryatia, Selenga

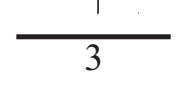

2 Buryatia, Temnik
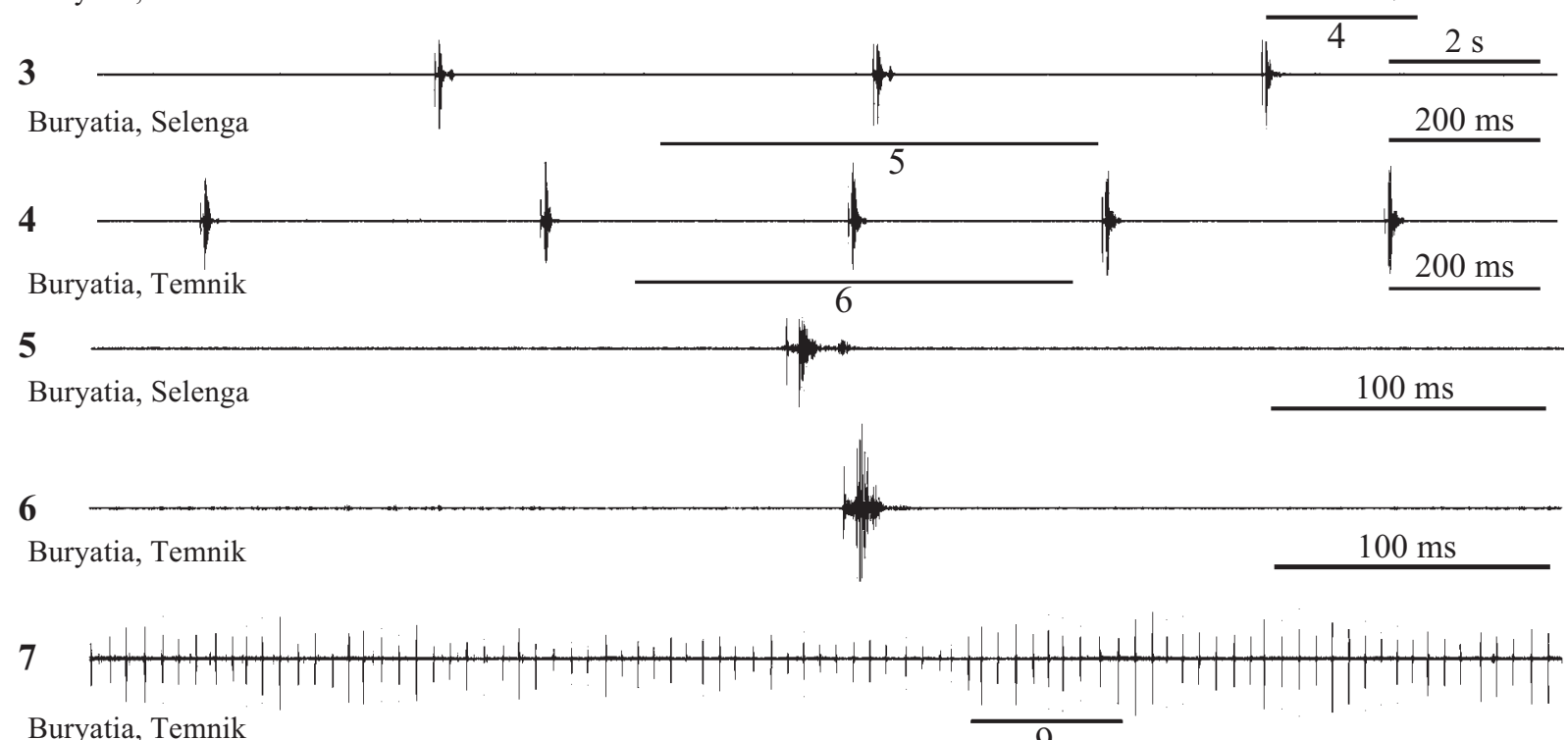

Buryatia, Temnik

9

$8 \mathrm{H}+\mathrm{H}+\mathrm{H}+\mathrm{H}+\mathrm{H}+\mathrm{s}$

Chita Area

9
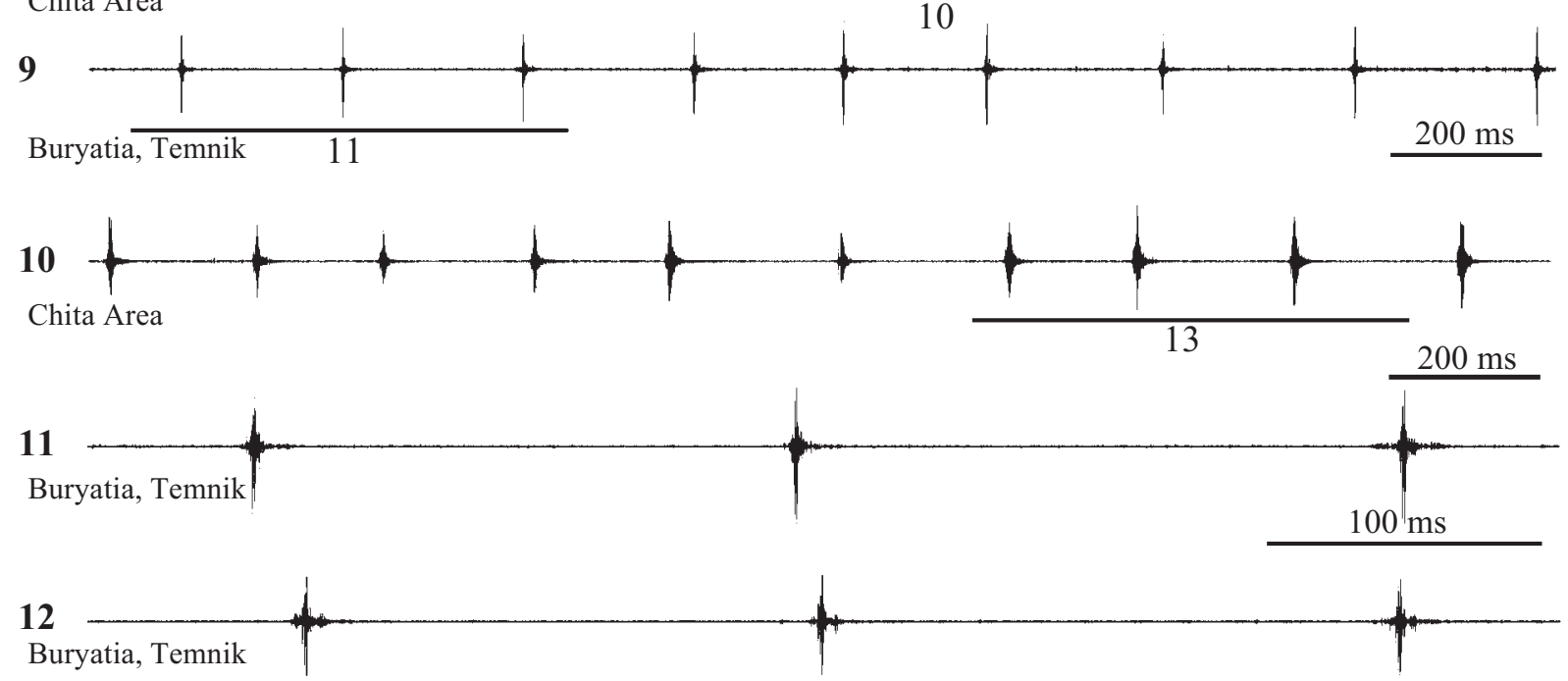

Buryatia, Temnik

13

Chita Area

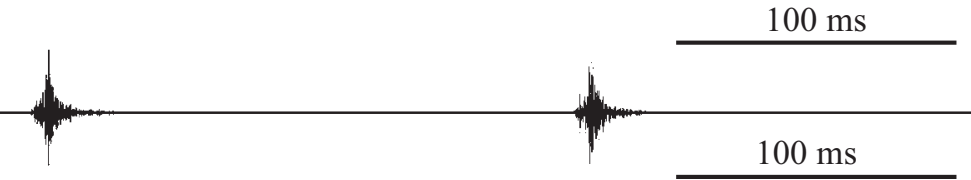

Figs 1-13. Oscillograms of acoustic signals of Bryodemini produced during flight displays: 1-6 - Bryodema luctuosum; 7-13 Bryodemella holdereri. Faster oscillograms of the parts of signals indicated as "3-6", "9-11" and "13" are given under the same numbers.

Рис. 1-13. Осциллограммы акустических сигналов Bryodemini, издаваемых во время демонстрационных полётов: 1-6 Bryodema luctuosum; 7-13 - Bryodemella holdereri. Фрагменты сигналов, помеченные цифрами “3-6”, “9-11” и “13”, представлены при большей скорости развёртки на осциллограммах под соответствующими номерами. 


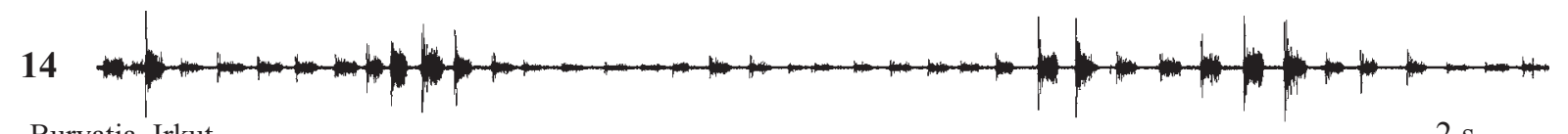

Buryatia, Irkut

$$
18
$$

15

Buryatia, Selenga

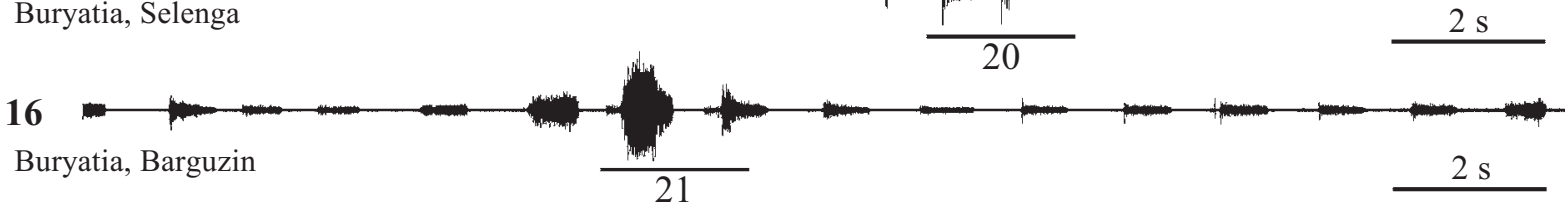

17

Volgograd Area

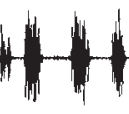

18

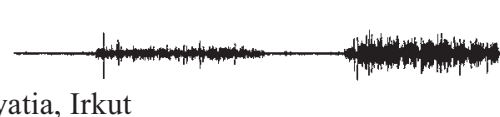

22
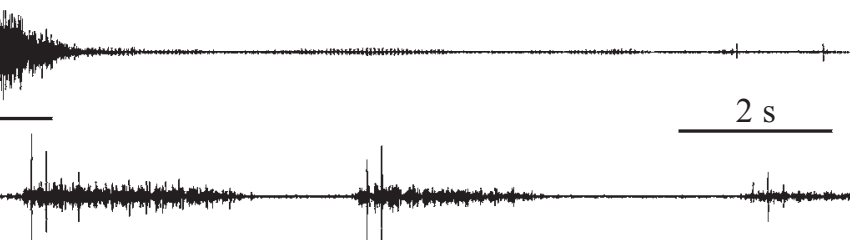

Buryatia, Irkut

$200 \mathrm{~ms}$

19

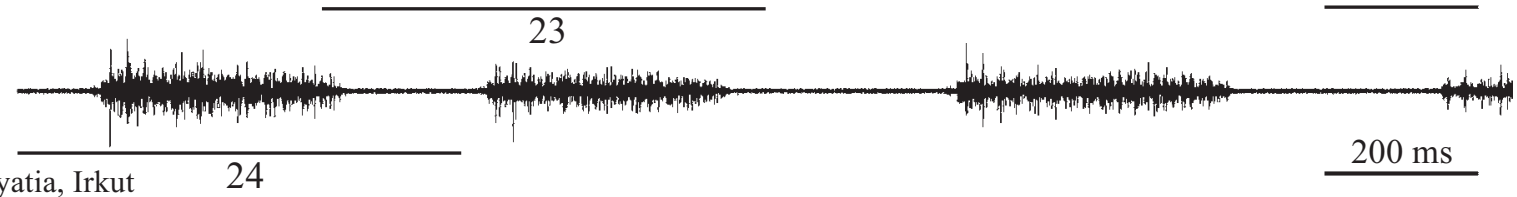

Buryatia, Irkut

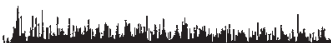

20

Buryatia, Selenga

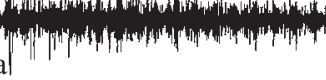

\section{5}

$200 \mathrm{~ms}$

21

Buryatia, Barguzin

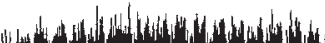

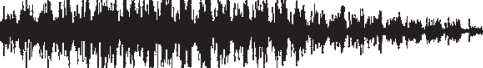

$$
26
$$

$200 \mathrm{~ms}$

22

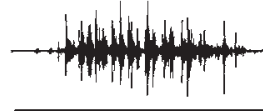

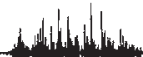
rintrinty

Volgograd Area 27

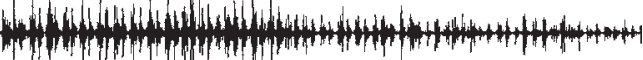

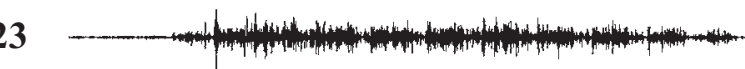

Buryatia, Irkut

24

If

Buryatia, Irkut

\section{5}

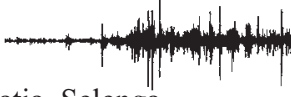

Buryatia, Selenga

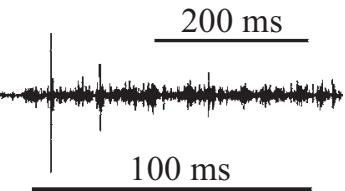

26

Buryatia, Barguzin

27

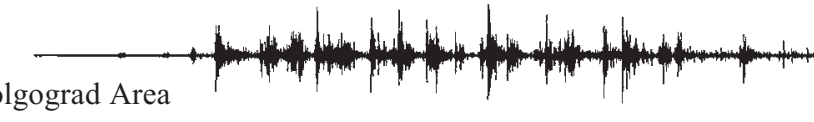

Figs 14-27. Oscillograms of acoustic signals of Bryodemella tuberculatum produced during flight displays. Faster oscillograms of the parts of signals indicated as " 18 " and " $20-27$ " are given under the same numbers.

Рис. 14-27. Осциллограммы акустических сигналов Bryodemella tuberculatum, издаваемых во время демонстрационных полётов. Фрагменты сигналов, помеченные цифрами “ 18 ” и “20-27”, представлены при большей скорости развёртки на осциллограммах под соответствующими номерами. 


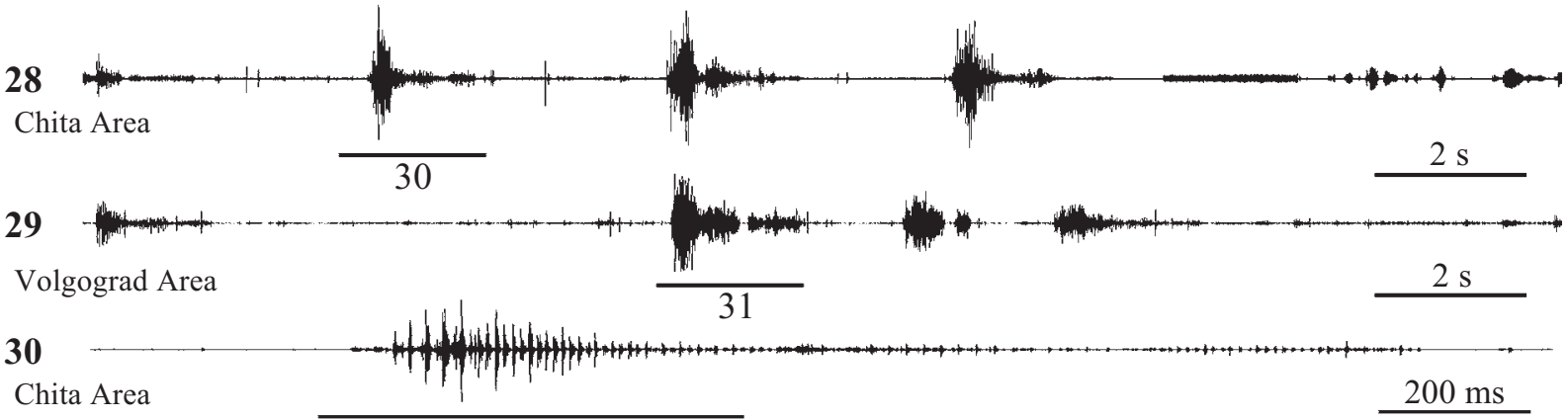

Chita Area

32 $31 \longrightarrow$ Volgograd Area

\section{2}

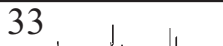

Chita Area

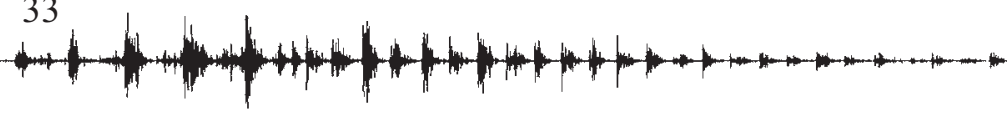

$100 \mathrm{~ms}$

\section{3}

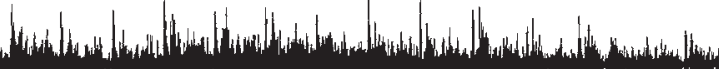

Volgograd Area

$34 \mathrm{HH}+\mathrm{H}+\mathrm{H}+\mathrm{H}+\mathrm{H}+\mathrm{H}+\mathrm{H}+\mathrm{H}+\mathrm{H}+\mathrm{HH}+\mathrm{H}+\mathrm{H}+\mathrm{HH}$

Buryatia, Temnik

36

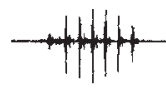

Buryatia, Temnik

37

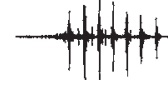

Buryatia, Selenga
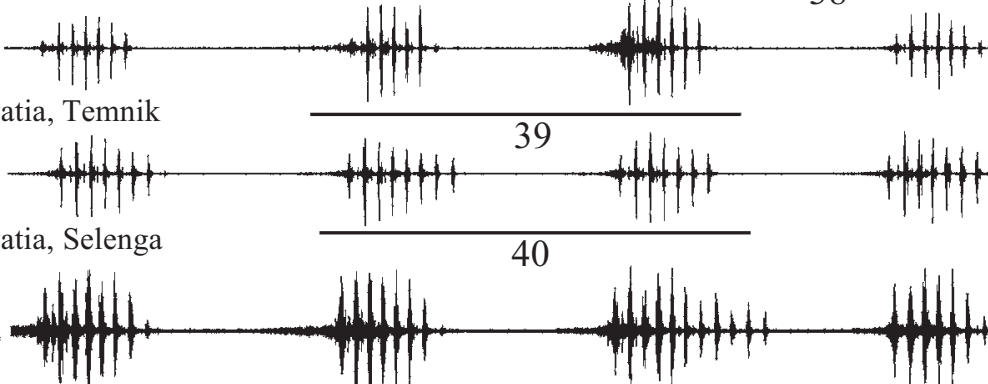

Chita Area

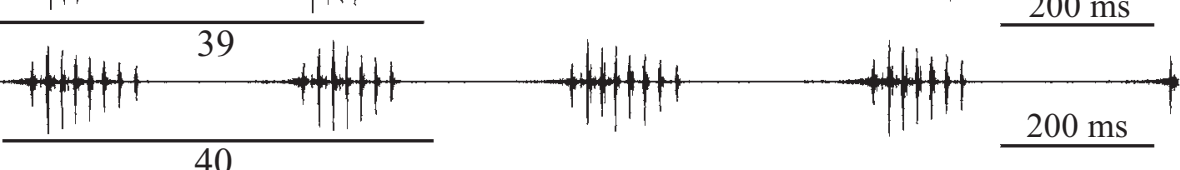

39

Buryatia, Temnik
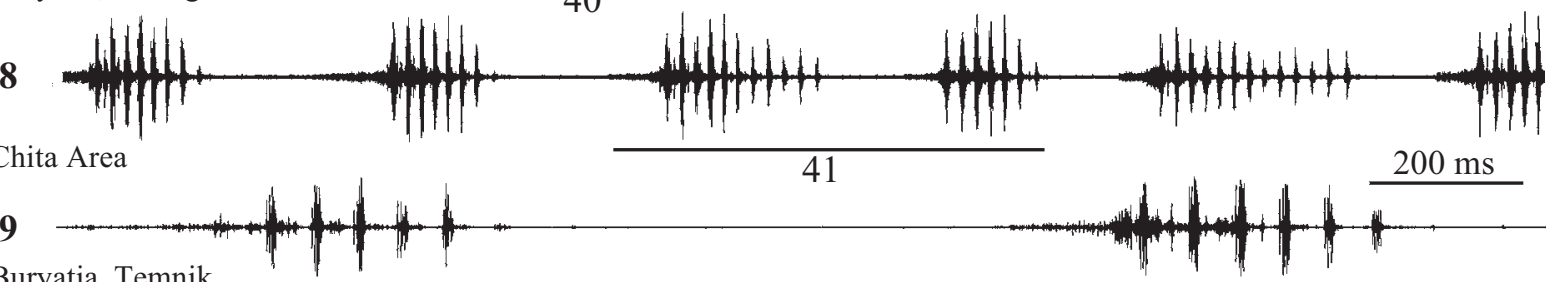

41

$200 \mathrm{~ms}$

40

Buryatia, Selenga
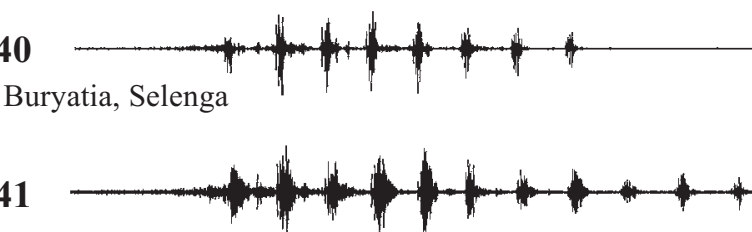

Chita Area

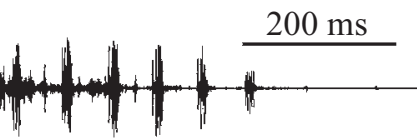

$100 \mathrm{~ms}$

Figs 28-41. Oscillograms of acoustic signals of Bryodemini: 28-33 - Bryodemella tuberculatum, signals of males flying in a straight line; 34-41 - Angaracris barabensis, signals produced during flight displays. Faster oscillograms of the parts of signals indicated as "3033 ", "36" and "38-41" are given under the same numbers.

Рис. 28-41. Осциллограммы акустических сигналов Bryodemini: 28-33 - Bryodemella tuberculatum, сигналы самцов, летящих по прямой линии; 34-41 - Angaracris barabensis, сигналы, издаваемые во время демонстрационных полётов. Фрагменты сигналов, помеченные цифрами “30-33”, “36” и “38-41”, представлены при большей скорости развёртки на осциллограммах под соответствующими номерами. 


\section{Discussion}

Comparative analysis shows that the songs of species studied can be classified in two groups. In the songs of $B$. luctuosum and $B$. holdereri syllables are very short and sound like abrupt clicks, whereas in B. tuberculatum dilutum and A. barabensis syllables are prolonged successions of pulses.

The songs of $B$. luctuosum and $B$. holdereri are quite similar to each other (Figs 1-13). The only minor difference can be seen in the temporal pattern of syllables (Figs 5-6 and 11-13). Mean syllable repetition period (SRP) in the former species is distinctly greater than in the latter one, still the ranges of variability of this parameter completely overlap (Fig. 42).

$B$. tuberculatum and A. barabensis differ clearly from each other in the song patterns (Figs 14-27 and 34-41). Comparison of temporal parameters of the signals in these two species is not always possible due to considerable difference in temperature between the daytime when $A$. barabensis is active and the evening when B. tuberculatum starts its flight displays. As in all other singing insects, both syllable duration and SRP in Bryodemini decrease with increasing temperature (Fig. 43). However, in recordings made at $28-30{ }^{\circ} \mathrm{C}$ the ranges of variation of syllable duration in two species do not overlap (Fig. 44) and the ranges of SRP overlap only partially averaging $300-530 \mathrm{~ms}$ in $A$. barabensis and 400-900 $\mathrm{ms}$ in B. tuberculatum dilutum.
B. luctuosum and B. holdereri quite often perform their flight displays simultaneously. Consequently, the similarity of the songs in these species is no barrier to their successful communication. Two suppositions can be made to explain this fact. First, the songs of two species clearly differ from each other in mean values of SRP (Figs 1-4 and 7-10); this difference is quite distinct for human ear under natural conditions. Similarly, the signals remain quite discernible on oscillograms when superimposed on the same axis (Fig 42, upper part). Second, B. luctuosum and B. holdereri also can use visual cues for recognition of conspecific mate, since they differ from each other in the hind wing coloration: blue in the former species and rose with dark fore margin in the latter one.

A. barabensis also as a rule performs flight displays together with two species mentioned above, but its song is quite dissimilar with these of B. luctuosum and B. holdereri.

B. tuberculatum dilutum and A. barabensis form another pair of species producing signals with similar temporal pattern. In spite of clear differences between the songs of B. tuberculatum dilutum and other Bryodemini studied both in structure and the duration of syllables, we have never observed $B$. tuberculatum dilutum performing flight displays simultaneously with any other species. As it was noted above, usually it is active at the dusk after sunset and, more rarely, also at the dawn. If numerous enough, B. tuberculatum dilutum

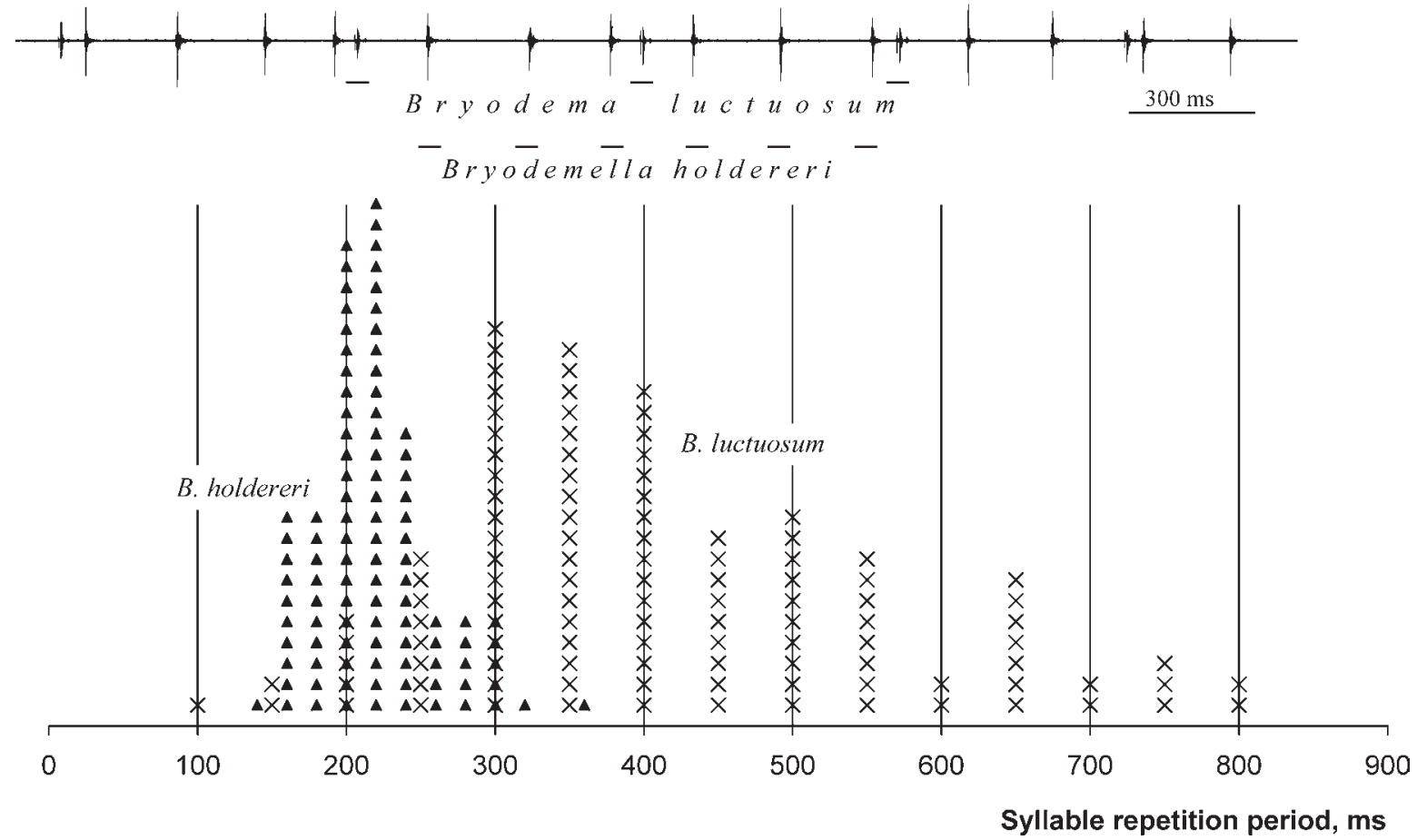

Fig. 42. Histograms of distribution of syllable repetition period values in the signals of Bryodemella holdereri and Bryodema luctuosum at the temperature $28-32{ }^{\circ} \mathrm{C}$. Upper part: oscillogram of the signals of both species superimposed on the same axis; in the middle part of oscillogram the syllables of each species are marked by horizontal lines above its name.

Рис. 42. Гистограммы распределения значений периода повторения серий в сигналах Bryodemella holdereri и Bryodema luctuosum при температуре $28-32{ }^{\circ} \mathrm{C}$. В верхней части - осциллограмма сигналов обоих видов, совмещённых на одной оси; в средней части осциллограммы серии в сигналах каждого вида помечены горизонтальными линиями, расположенными над его названием. 


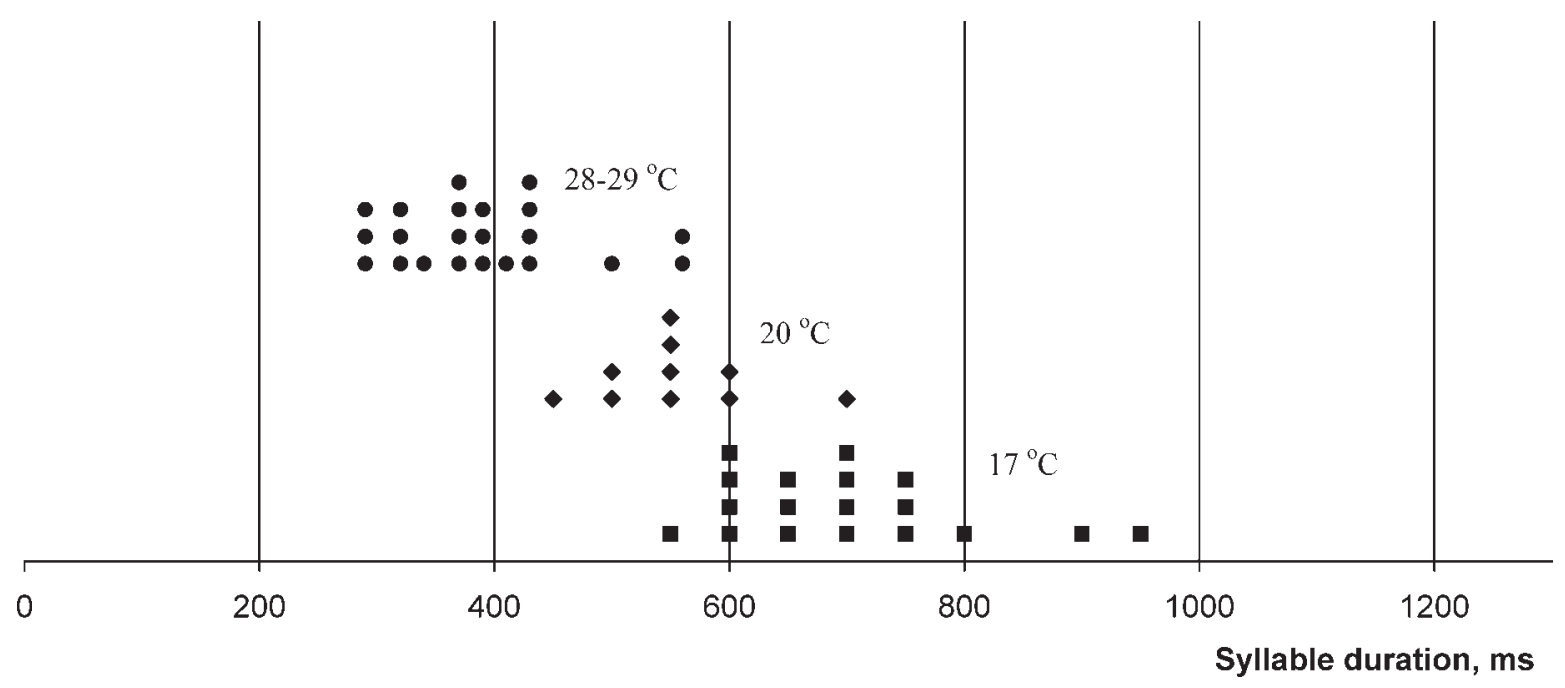

Fig. 43. Histograms of distribution of syllable duration values in the signals of Bryodemella tuberculatum dilutum at different temperatures.

Рис. 43. Гистограммы распределения значений длительности серий в сигналах Bryodemella tuberculatum dilutum при разных температурах.

forms so-called dusk chorus, which is a short abrupt outbreak of acoustic activity of singing animals after sunset; previously this phenomenon was observed only in tropical ecosystems. We failed to find any descriptions of dusk chorus in temperate zone, as well as any data on the timing of flight displays of $B$. tuberculatum dilutum. Only Berezhkov [1956] reports that this species usually performs flight displays in the afternoon. Thus, the peculiar behaviour of $B$. tuberculatum dilutum remained unnoticed by the most part of specialists even if it was described anywhere. The question arises about the reasons for such a drastic shift of the time of acoustic activity of $B$. tuberculatum dilutum.

$B$. tuberculatum dilutum and $A$. barabensis sometimes are similar in hind wing coloration: rose in the former species and either rose or greenish in the latter one. As a result, visual cues are not always reliable for recognition of conspecific individual in this case. The songs of two species differ distinctly from each other in temporal pattern (Figs 14-27 and 34-41) and theoretically could provide reliable species-specific characters. It should be taken into account, however, that both species quite often live in dense populations. Under such conditions a great number of individuals perform flight displays almost at a time so that their signals sound as unceasing loud crepitation. Presently, it is known, that acoustic signals of different species communicating in the same habitat may suffer mutual interference and masking. For this reason sympatric bird species adjust the temporal patterning of their singing in such a way as to avoid temporal overlap with the songs of each other [Cody \& Brown, 1969; Ficken et al., 1974]. Similarly, strong partitioning of singing time exists between the members of tropical dusk chorus [Riede, 1996]. In the singing cicadas (Homoptera, Cicadidae) an examples of diel and seasonal shifts of the periods of acoustic activity in relation to the species composition of the community are described [Wolda, 1993]. It should be emphasised that in such cases the songs of different species within the community differ from each other in physical characters, still the singing of one species may jam the signals of another one.

Apparently, the situation with $B$. tuberculatum dilutum and $A$. barabensis provides one more example of this kind. Simultaneous singing of a great number of individuals of one species makes communication of another one impossible, because the signals of two species jam each other. As can be seen from oscillograms superimposed on the same axis, the songs of $B$. tuberculatum dilutum and $A$. barabensis become hardly distinguishable when overlap (Fig. 44, upper part). Evidently, this is the reason for temporal shift of $B$. tuberculatum dilutum activity peak and the emergence of dusk chorus in this species. It is remarkable, that in the valley of Irkut River $A$. barabensis was not found and B. tuberculatum dilutum started its flight displays 3-4 hours earlier (i.e. about 2 hours before sunset) than in all other localities where our observations were made.

In our previous works we have shown that grasshopper species producing calling signals with similar temporal patterns always demonstrate segregation of communication channels either being allopatric or inhabiting different biotopes within the same territory [Tishechkin, 2008; Tishechkin \& Bukhvalova, 2010]. An example of Bryodemini shows that in certain cases acoustic signals of different species suffer mutual interference even though they differ distinctly from each other in temporal pattern. Moreover, in the case being considered segregation of communication channels is provided through the divergence of the periods of acoustic activity of the members of the community, which is an exceptional case for grasshoppers. 

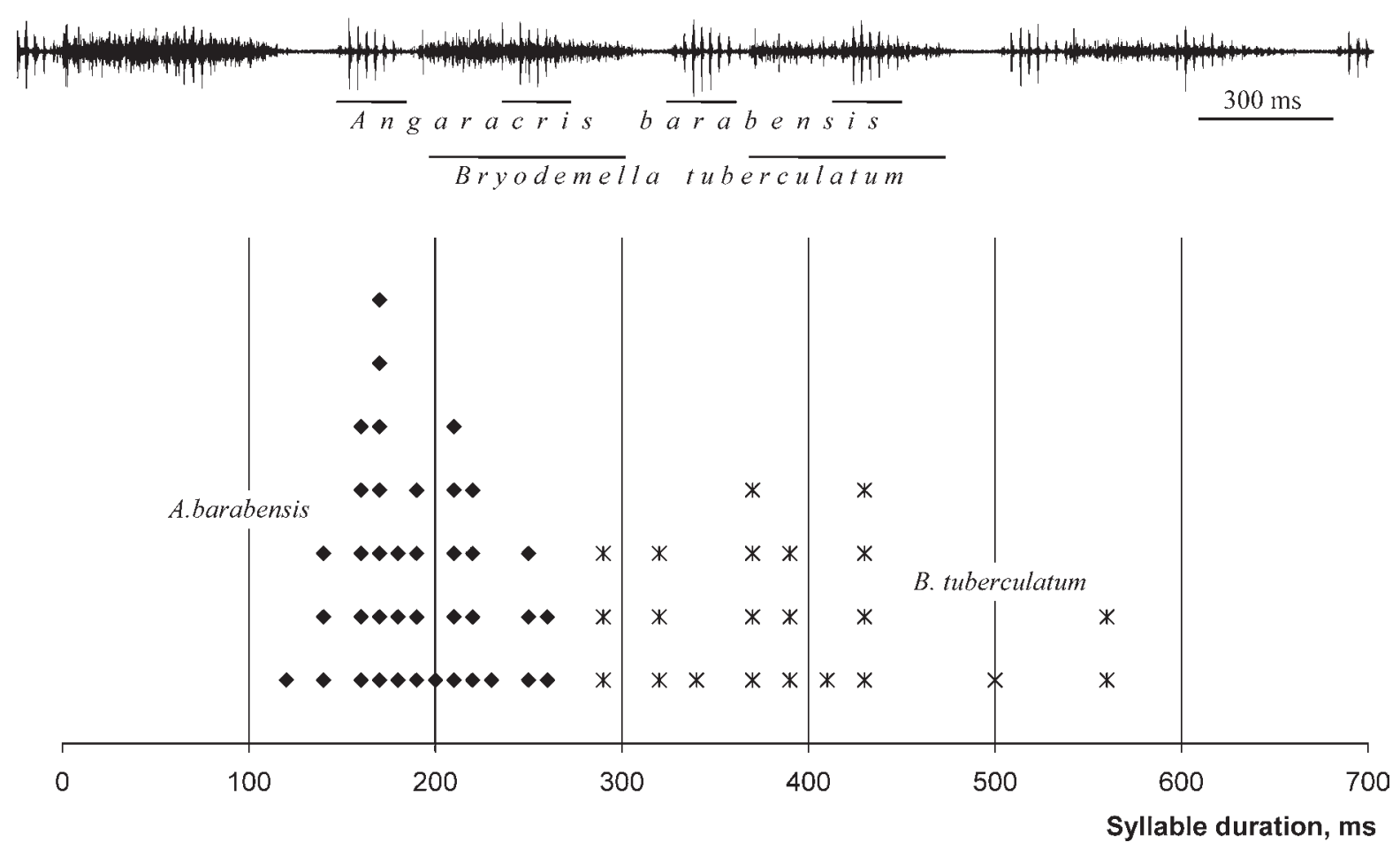

Fig. 44. Histograms of distribution of syllable duration values in the signals of Angaracris barabensis and Bryodemella tuberculatum dilutum at the temperature $28-32{ }^{\circ} \mathrm{C}$. Upper part: oscillogram of the signals of both species superimposed on the same axis; in the middle part of oscillogram the syllables of each species are marked by horizontal lines above its name.

Рис. 44. Гистограммы распределения значений длительности серий в сигналах Angaracris barabensis и Bryodemella tuberculatum dilutum при температуре $28-32{ }^{\circ} \mathrm{C}$. В верхней части — осциллограмма сигналов обоих видов, совмещённых на одной оси; в средней части осциллограммы серии в сигналах каждого вида помечены горизонтальными линиями, расположенными над его названием.

ACKNOWLEDGEMENTS. I am greatly indebted to my friend and colleague Dr. K.A. Kolesnichenko (Botanical Garden of the Moscow State University, Russia) for his invaluable help during our expeditions to the steppe regions of South Siberia and to Dr. Dai Wu (Entomological Museum, Northwest A\&F University, Yangling, Shaanxi, China) for sending the necessary articles from chinese issues. The study was supported by Russian Foundation for Basic Research (No. 10-04-00275-a) and a grant of a State Program "Development of Scientific Potential of Higher School" (project No. RNP.2.1.1.3267 "Ecosystem Functions, Mechanisms of Reproduction and Evolution of Biological Diversity").

\section{References}

Benediktov A.A. 1998. [On the systematics of palaearctic representatives of the tribe Bryodemini (Orthoptera: Acrididae)] // Zoologicheskiy Zhurnal. Vol.77. No.7. P.788-799 [in Russian, with English summary].

Berezhkov R.P. 1956. [Grasshoppers of West Siberia]. Tomsk, Tomsk University Press. 175 pp. [in Russian].

Bukhvalova M.A. 2006. Partitioning of acoustic transmission channels in grasshopper communities // S. Drosopoulos, M.F. Claridge. (eds.). Insect Sounds and Communication. Physiology, Behaviour, Ecology and Evolution. Boca Raton, London, New York: CRC Press, Taylor and Francis Group. P. 199-205.

Cody M.L. \& Brown J.H. 1969. Song asynchrony in neighbouring birds species // Nature. Vol. 222. P. 778-780.
Ficken R.W., Ficken M.S. \& Hailman J.P. 1974. Temporal pattern shifts to avoid acoustic interference in singing birds // Science. Vol.183. P.762-763.

Ragge D.R. \& Reynolds W.J. 1998. The songs of the grasshoppers and crickets of Western Europe. England: Harley Books (in association with The Natural History Museum, London). 591 p.

Riede K. 1996. Diversity of sound-producing insects in a Bornean lowland rain forest // Tropical Rainforest Research. Kluwer Acad. Publ., Netherlands. P.77-84.

Savitsky V.Yu. \& Lekarev A.Yu. 2007. [New data on acoustic communication and sexual behaviour of grasshoppers (Orthoptera: Acrididae) from semi-deserts and deserts of Russia and adjacent countries] // Russian Entomol. J. Vol.16. No.1. P.1-38 [in Russian, with English summary].

Tishechkin D.Yu. 2008. Calling songs of grasshoppers of the genus Podismopsis (Orthoptera: Acrididae: Gomphocerinae) and potentialities of use of acoustic characters for discrimination between species of the genus // Russian Entomol. J. Vol.17. No.3. P.259-272.

Tishechkin D.Yu. \& Bukhvalova M.A. 2010. Acoustic communication in grasshopper communities (Orthoptera: Acrididae: Gomphocerinae): segregation of acoustic niches // Russian Entomol. J. Vol.18 (for 2009). No.3. P.165-188.

Wolda H. 1993. Diel and seasonal patterns of mating calls in some Neotropical Cicadas. Acoustic interference? // Proc. Koninklijke Nederlandse Akademie van Wetenschappen. Vol.96. No.3. P. 369-381.

Xi R., Liu J., He Z. \& Chen N. 1992. [Studies of sound structure of the acridoids] // Sinozoologia. No.9. P.35-42 [in Chinese, with English summary]. 